\title{
Asa Gray and Charles Darwin: Corresponding Naturalists
}

\section{Citation}

Browne, Janet. 2010. Asa Gray and Charles Darwin: Corresponding naturalists. Harvard Papers in Botany 15(2): 209-220.

\section{Published Version}

doi:10.3100/025.015.0204

\section{Permanent link}

http://nrs.harvard.edu/urn-3:HUL.InstRepos:10459023

\section{Terms of Use}

This article was downloaded from Harvard University's DASH repository, and is made available under the terms and conditions applicable to Open Access Policy Articles, as set forth at http:// nrs.harvard.edu/urn-3:HUL.InstRepos:dash.current.terms-of-use\#OAP

\section{Share Your Story}

The Harvard community has made this article openly available.

Please share how this access benefits you. Submit a story.

Accessibility 
Asa Gray and Charles Darwin: Corresponding Naturalist

Janet Browne

Department of the History of Science

Harvard University

Science Center 371

Cambridge

MA 02138

Abstract

Recent work on the rise of science in the nineteenth century has encouraged historians to look again at the role of correspondence. Naturalists relied extensively on this form of contact and correspondence was a major element in generating a community of experts who agreed on what comprised valid knowledge. As a leading figure in the development of North American botany, Asa Gray found that letters with botanists and collectors all over the world greatly expanded his areas of influence. Lasting friendships were made and the collections at Harvard were materially advanced. Letters also brought Gray into contact with Charles Darwin, who became a close friend. After publication of Darwin's Origin of Species Gray defended Darwinism in the United States and corresponded with him about evolution. This article sets Gray's correspondence with Darwin in the context of the reception of Darwinism in the United States.

Keywords: history, botany, correspondence, Darwinism, evolution 
When Charles Darwin died on 18 April 1882, Asa Gray lost not only a lifelong friend but also his closest intellectual partner in the development and dissemination of Darwinism in the United States. Gray had known Darwin since 1851. They had first been introduced by the botanist Joseph Dalton Hooker, during Gray's visit to Europe in 1839, though both men later forgot this chance meeting; and they met twice thereafter on English soil. Gray and his wife enjoyed a personal visit to Darwin's home in Kent in 1868, and again in 1881. Darwin was "entirely fascinating" commented Mrs. Gray that first weekend. He was "tall \& thin, though broadframed, \& his face shows the marks of suffering and disease ... He never stayed long with us at a time, but as soon as he had talked much, said he must go \& rest." He had "the sweetest smile, the sweetest voice, the merriest laugh! and so quick, so keen!” (Dupree 1988, p.338). Over dinner, she told Darwin about her sister's dog that washed its face like a cat, a story that eventually made its way into his writings. The scientists at other times exchanged photographs and eagerly discussed the progress of evolutionary ideas in North America, an area in which Gray became the outstanding expert of the nineteenth century. Some fourteen years later the news of his friend's death was a terrible blow. Gray wrote to a member of the Darwin family to say Darwin's death was "like the annihilation of a good bit of what is left of my own life."

The story of Gray and Darwin's relationship was perceptively told in Hunter Dupree's classic biography of Gray, published in 1959 and reprinted in 1988. However the bicentenary in 2010 of Gray's birth encourages us to look again at this remarkable convergence of intellectual interests and personal friendship, and to refocus on Gray as the main gateway by which Darwin's ideas 
entered the United States. Not least in this endeavour was Gray's role in ensuring rapid publication of the first American edition of the Origin of Species, followed by 19 other American editions of the Origin in Darwin's lifetime, plus editions of his later works, several of which included material in advance of the English editions (Freeman 1977, 112-24). But Gray was far more than a mere facilitator for the transmission of European ideas although he adopted this role very effectively. He was the most famous and widely read commentator on Darwin's Origin of Species in the United States and one of the nation's most active promoters of evolutionary ideas-yet still publicly retaining his belief in a creator. By writing a number of tracts on the possibility of reconciling evolutionary proposals with theistic belief, Gray smoothed the introduction of Darwinian ideas in America in ways that Thomas Henry Huxley, his fire-andbrimstone contemporary, was unable to replicate in England.

Figure 1, Figure 2 to go near here

These achievements come more boldly into the spotlight if the social setting of science in the nineteenth century is brought into play. Natural history mostly operated via a scholarly network somewhat different from today. Along with opportunities to meet in person through local institutions, learned societies, conferences, and field-clubs, and an increasing opportunity to publish and read about the work of their colleagues in rising numbers of periodicals and journals, naturalists relied extensively on correspondence to ensure the circulation of scientific information. This perhaps is a truism as regards those naturalists located in Europe but bears repetition when thinking of the young republic. As a leading figure in the institutional development of North American botany, Asa Gray found that the exchange of letters with 
botanists and collectors was the best method for augmenting his areas of influence. Much of his extant correspondence indicates the range and number of his daily communications with local collectors, many of them situated in key botanical areas of the United States (J. L. Gray 1893) ${ }^{1}$. Other letters went regularly to botanists elsewhere in the world. In those early years of national expansion, and then as Gray's teaching, publishing ventures, and researches expanded, lasting friendships were made and the botanical collections at Harvard were materially advanced.

This correspondence was also a major element in generating a community of experts who agreed on what comprised valid knowledge. Correspondence used to be one of the main ways that scientists in all disciplines collected, processed, and disseminated data. Charles Darwin has been a popular figure for attention, but other individuals were just as prolific in generating correspondence networks, such as comparative anatomists and museum directors like Georges Cuvier or Richard Owen who respectively ran the great natural history museums in Paris and London; Spencer Baird, the director of the Smithsonian Institution; William and Joseph Hooker, successive directors of the Royal Botanic Gardens at Kew in London; or as Roderick Home and Arthur Lucas have shown in their recent publications, geographically far-flung naturalists such as Ferdinand Mueller, whose correspondence as first director of the Botanic Gardens in Melbourne runs to 11,500 extant items (Home and Lucas 1998-2006). The great size of these archival resources suggests that the natural history sciences were particularly open to the generation of such networks. For example, it was mainly by supplementing and comparing his observations with knowledge gathered from thousands of letters after his return to Europe, that Alexander von Humboldt was able to reflect on how those variables related to one another throughout the 'cosmos'. Using letters as a research tool in this respect substantially increased

\footnotetext{
${ }^{1}$ The bulk of Gray's manuscripts are in the Library, Gray Herbarium, Harvard University. See http://www.huh.harvard.edu/libraries for an inventory.
} 
the amount of information to which each naturalist had access, a sort of written accompaniment to the expanding boundaries of the developed world, or a globalisation of science as pervasive in its own way as colonial extension. Gray and Darwin became friends through their letters. But they were also participating in a robust, worldwide communication system that characterised the era and was particularly suited for the pursuit of the observational sciences.

Gray's role in the reception of evolution by natural selection has been somewhat obscured by the high public profile of other evolutionists. Nevertheless one could think of the response to Darwin's Origin of Species as an informally organized movement held together by personal ties and scientific commitment (Browne 2002, 2006). After publication of the Origin in 1859 Darwin's closest friends acted almost as if they were the four musketeers of Alexandre Dumas's fictional tale, dividing up the intellectual world between them. Huxley dedicated most of his scientific ammunition to the issue of possible ape ancestry for humans. Charles Lyell, one of Darwin's oldest friends, took on the domain of geology and the fossil record, while Joseph Hooker opted for the botanical world in all its diversity, from colonial gardens to popular magazines. Asa Gray became gatekeeper for North America.

This was not necessarily something that might have been expected. Like Huxley, Gray had previously disliked the theory of transmutation and had rejected Robert Chambers' evolutionary tract Vestiges of the Natural History of Creation when it was anonymously published in the United States in 1845 (Gray 1846, Dupree 1988, 143-8). ${ }^{2}$ Yet Gray had never been comfortable with the dry intellectual tools of his trade, and was independently coming to see plant species as disconcertingly fluid units, not easy to define at the boundaries. He was a confirmed empiricist-one of the few hardline empiricists in the transcendental mist of Emerson's, Thoreau's,

\footnotetext{
${ }^{2}$ Gray's annotated copy of Vestiges of the Natural History of creation (1845) is in the library of the Gray Herbarium, Harvard University.
} 
Agassiz's, and Lowell's America. He avoided talk about "abstract types," scorning romanticism in the sciences while appreciating the transcendentalists' adherence to a belief in the divine in mankind (Dupree 1988, 174-232 passim). His growing relationship with Darwin encouraged him to think systematically about species and to appreciate the analytic writings of contemporary European botanists such as Augustin De Candolle. When Darwin tentatively began explaining his own evolutionary views to Gray by letter, Gray was intrigued. Instead of rejecting Darwin's proposals, at that point only known to a few confidants, he energetically critiqued the new approach, making Darwin exclaim in July 1855:

Your discussion on connecting \& separating forms seems to me so philosophical, that I much hope that someday you will be as good as your word \& write an 'Essay on Species' (Burkhardt and Smith 5:384)

Then, come what may, Gray found himself thoroughly caught up in the evolutionary debate.

Figure 3 to go near here

In 1857, Darwin wrote Gray a longer letter than usual in which he spelled out his vision of "descent with modification." In retrospect it is clear that Darwin intended this letter to be an upto-date resume of his evolutionary work, which, in the 1850s, was still developing and deepening. It was expressed in words appropriate to a scientific equal, with no special regard to the larger cultural consequences of evolutionary theory. Darwin was at that point writing what he called his big book on species and was methodically pulling together his own research, 
including experiments at his home on a wide variety of organisms, with results drawn from extensive correspondence with relevant experts around the world. Information on barnacles, pigeons, seed transportation, comparative statistics of plant distribution, ecological divergence, the structure of bees' cells, and much more besides, all contributed to the development of Darwin's mature theory of natural selection. Much of this recent work rested on ideas that Darwin was deriving from Gray about plant distribution and comparative statistics of the incidence of varieties and species in large or small genera (Browne 1980). By September 1857 he felt ready to summarize for himself and simultaneously explain it to Gray.

It was lucky that Darwin kept a rough copy (Burkhardt and Smith 6, 445-50). The following year, when Alfred Russel Wallace unexpectedly sent Darwin an essay describing his independent formulation of the same notion of evolution by natural selection, Darwin turned to his correspondence with Gray to verify his priority. Even though the story of this 'simultaneous discovery' between Darwin and Wallace has often been told, few scholars today recall Asa Gray's central place in the business. Darwin, with encouragement from his English naturalist friends, Joseph Hooker and Charles Lyell, expressly chose his 1857 letter to Gray to serve as evidence that he had, about a year earlier, described his theory in terms remarkably similar to Wallace's. When the decision was taken to publish Wallace's essay with extracts from Darwin's writings, Darwin thus decided to include his letter to Gray. Acting quickly, and under pressure from Hooker and Lyell, there was no time to ask Gray to send the original handwritten letter back across the Atlantic. Instead Darwin sent the retained rough copy, along with earlier writings, as his contribution to the joint papers on evolution by natural selection put before the Linnean Society on 1 July 1858 by Hooker and Lyell. The material was subsequently published in the Linnean Society Journal (Darwin and Wallace 1858). 
From then onwards, Gray was indelibly associated with the new ideas. This perfectly suited his inclinations - rarely has a developing friendship intermeshed so closely with exhilarating intellectual change and a publishing phenomenon like the Origin of Species. And although he could not have seen it then, by linking himself with the progress of Darwinism there were many associated prospects for professional advancement and the expansion of science in North America. Not least, Gray understood that the Origin represented the first serious alternative to Agassiz's biology. He adopted many of the points of view expressed in Darwin's Origin and began to promote the book at every opportunity. In the process, he became close friends (by letter) with the English Darwinists, principally Huxley, Hooker, and Lyell.

Almost immediately these men took on the task of defending, promoting, and extending Darwin's ideas. As described by Hunter Dupree, Gray ensured that everything from Darwin's pen that was destined for the Americas passed through his own hands, a privilege he guarded zealously. He first opened negotiations on Darwin's behalf with Ticknor and Fields, the Boston publishing house with which Gray had excellent personal relations. Yet a number of pirate copies of the Origin of Species were already circulating in New York, rushed out by the firm of Appleton's in the first few weeks of 1860 without Darwin's knowledge. Gray therefore prevented any further entrepreneurial activity by dropping Ticknor and negotiating directly with William Henry Appleton in New York, promising that in exchange for a proper publishing contract he would supply a fully authorised text, complete with Darwin's endorsement. Appleton agreed and the first authorized US edition, numbering 2500 copies, was published in May 1860, carrying on the title the words "New edition, revised and augmented by the Author." (Darwin 1860, Freeman 1977, item 380, p.113). For this Gray sent Darwin a cheque for 21 guineas (Burkhardt and Smith 8, 53-4). His copy of the volume is today in the Gray Herbarium, with 
some significant comments by Gray on the endpapers. "Most sincerely do I thank you from my heart for all your generous kindness \& interest about my book," Darwin wrote to him (Burkhardt and Smith8, 223).

As well as ensuring that Darwin's theories were accurately represented in the American world, Gray defended Darwin against attacks and wrote three important reviews in as many months for leading North American journals (Gray 1860a, 1860b, 1860c, reprinted in Gray 1888. See also Sargent 1889). He put himself forward as a major intellectual rival to Louis Agassiz, tussling with Agassiz over the definition of species in a series of public meetings in Boston during 1860 and 1861, asking whether species were metaphysical constructs, created by God according to a transcendent plan, as Agassiz declared, or whether they arose by natural means from the processes of variation and adaptation, as Darwin proposed. Gray's empirical understanding of plant affinities enabled him relatively easily to adopt the idea of real 'genetic' relationships, as proposed by Darwin. Gray shamelessly enjoyed these fights, a contest bound up with his university-based power struggle with Agassiz; and he found an authoritative ally in William Barton Rogers, the geologist later to become first president of Massachusetts Institute of Technology. Gray and Rogers understood that Agassiz was the only man in America to possess the stature and influence to crush theories that did not meet his approval; and the resulting controversy in Massachusetts matched anything that Huxley and Bishop Wilberforce could provide in Britain. Rogers argued with Agassiz in a series of four evening meetings at the Boston Society of Natural History, showing that Darwin's views would not collapse like a pack of cards under Agassiz's wrath as had other transmutation theories such as those in Vestiges. In turn Gray harassed Francis Bowen, who opposed Darwin on philosophical grounds, at the American Academy of Arts and Sciences, also located in the Boston area. 
Gray launched his reviews in the American Journal of Science and Arts in March 1860 (Gray 1860a). The journal was run by James Dwight Dana and Benjamin Silliman Jr., two clever brothers-in-law at Yale, whom Gray, Darwin, and Agassiz knew well. Agassiz retaliated by writing a bitter commentary on species, also published in the American Journal, and in other natural history periodicals reiterated his definition of divine creation. Gray responded with another review, this time in the form of a dialogue, which included a measured response to Agassiz (Gray 1860b). Every one of Gray's words "tells like a 32-pound shot" said Darwin appreciatively.

Gray plagued Agassiz privately as well, hounding him at Harvard University seminars. The Origin, Agassiz said dismissively during those first weeks, was "poor--very poor." (F.Darwin 1887, vol.2:268). Gray's pro-Darwinian mood was strengthened by the admiration for the Origin of Species expressed by Jeffries Wyman--the Harvard professor of anatomy whom Gray thought "the best of judges". Dawdling around the fire in Wyman's college rooms at Christmas time in 1859, a group of East coast friends grew “warm discussing the new book of Mr Darwin's." James Russell Lowell, Henry Torrey, and Charles Eliot Norton were there with Wyman and Gray (Dupree 1988, 267). Month by month, Grey sent Darwin copies of local reviews and verbal reports about the progress of natural selection in the New World.

The regard was mutual. Darwin admired Gray's tactical successes, and valued his philosophical acumen. "I declare that you know my book as well as I do myself; \& bring to the question new lines of illustration $\&$ argument in a manner which excites my astonishment $\&$ almost my envy!" he said as Gray's reviews of the Origin came out. Gray's talents were wasted on plants, he joked. "You ought to have been a lawyer, \& you would have rolled in wealth by perverting the truth, instead of studying the living truths of this world." (Burkhardt and Smith 
8:298). Later, Darwin made the point again with feeling. "I said in a former letter that you were a lawyer; but I made a gross mistake, I am sure that you are a poet. No by Jove I will tell you what you are, a hybrid, a complex cross of Lawyer, Poet, Naturalist, \& Theologian!-- Was there ever such a monster seen before?"(Burkhardt and Smith 8:350). Soon he was convinced that "no other person understands me so thoroughly as Asa Gray. If I ever doubt what I mean myself, I think I shall ask him!" (Burkhardt and Smith 8:405).

This regard for Gray drew Darwin onwards into discussions about faith and question of design in nature. Their correspondence repeats in localized form the same doubts and inquiries explored more generally by many people encountering rapid religious, social, and industrial upheavals in the middle years of the nineteenth century, soon to be intensified by war. Gray had not given up his religious belief upon reading the Origin - few readers did. His difficulties in the years following publication rested more on trying to align his personal faith with his commitment to rational science-and Gray became one of the most prominent figures in North American science to assert that the two were compatible.

These views were most obviously reflected in a series of letters from 1860 to 1862 in which Gray attended closely to the question of whether perfect adaptations could emerge without God's loving intervention. His questioning took added force after his reading of Darwin's 1862 work on orchids (Darwin 1862). Could the exquisitely adapted relationships between orchids and the insects that bring about their fertilization be due to mere chance, as Gray put it? He and Darwin exchanged detailed and engagingly earnest letters on this issue of 'design'.

In essence, Gray believed that adaptations-for example the mutual co-adaptations between insect and plant--reflected the thought and intent of a Creator, however such a deity might be understood. But he also recognised the value of Darwin's notion of natural selection. In letters 
and reviews he volunteered a compromise solution in which useful or favourable variations were generated in organisms by God. Natural selection could then 'pick' or select these in the competition for life. Gray, in effect, wanted to have it both ways: a divine agency could carry on supervising nature, for it was the Almighty who introduced favourable variants; and natural selection could act just as Darwin had proposed, as an objective, mechanical, winnowing force that tailored organisms to their surroundings. In making this suggestion, Gray was to differ markedly from other creative evolutionists or those who espoused providential evolution. He gave Darwin his due and did not make God the selecting agent.

Darwin understood the dilemma. Close friends such as Lyell experienced the same difficulty. But he was frank. "I grieve to say that I cannot honestly go as far as you do about design." Nevertheless, he told Gray he was perplexed. "I cannot think that the world, as we see it, is the result of chance; \& yet I cannot look at each separate thing as the result of design" (Burkhardt and Smith 8:496). It seemed to Darwin that Gray reiterated the age-old claim that the creator can preordain events. What of "necessity \& Free-will," and the "Origin of evil?" he inquired, subjects "quite beyond the scope of the human intellect." (Burkhardt and Smith 8:106).

With respect to the theological view of the question; this is always painful to me.-- I am bewildered.-- I had no intention to write atheistically. But I own I cannot see, as plainly as others do, \& as I shd. wish to do, evidence of design $\&$ beneficence on all sides of us. There seems too much misery in the world. I cannot persuade myself that a beneficent \& omnipotent God would have designedly created the Ichneumonidae with the express intention of their feeding within the living bodies of caterpillars, or that a cat should play with mice. Not believing this, I see no necessity in the belief that the eye was expressly 
designed. On the other hand I cannot anyhow be contented to view this wonderful universe $\&$ especially the nature of man, \& to conclude that everything is the result of brute force. I am inclined to look at everything as resulting from designed laws, with the details, whether good or bad, left to the working out of what we may call chance. Not that this notion at all satisfies me. I feel most deeply that the whole subject is too profound for the human intellect. A dog might as well speculate on the mind of Newton (Burkhardt and Smith 8:224).

Gray gave him a sympathetic ear. Decades afterwards, Darwin said that around this time he probably deserved to be called a deist (Barlow 1958, 92-3).

Gray's letters on design evidently helped Darwin clarify his mind. In the closing pages of Variation of Animals and Plants under Domestication (Darwin 1868) Darwin provided an explanation of the crucial difference between variation and selection. In those days, it was not always apparent that these were distinct processes--indeed perhaps only Darwin, with the advantage of many years thinking about the distinction, and a handful of experienced French and German experimentalists, were able easily to separate them (Gayon and Zallen 1998). Investigators more usually felt there was some form of inbuilt direction in the process of variation--they put back into the evolutionary system the purpose that Darwin removed. Asa Gray, in particular, advocated this view. In Variation Darwin politely but deliberately refuted Gray's opinion.

If an architect were to rear a noble and commodious edifice, without the use of cut stone, by selecting from the fragments at the base of a precipice wedge-shaped stones for his 
arches, elongated stones for his lintels, and flat stones for his roof, we should admire his skill and regard him as the paramount power. Now, the fragments of stones, though indispensible for the architect, bear to the edifice built by him the same relation which the fluctuating variations of each organic being bear to the varied and admirable structures ultimately acquired by its modified descendants. . . Can it reasonably be maintained that the Creator intentionally ordered, if we use the words in any ordinary sense, that certain fragments of rock should assume certain shapes so that the builder might erect his edifice? (Darwin 1868, 2:430).

Although the architect or builder would always choose the best stones for building a house, the shapes of the stones themselves were completely random--or rather, their geological production was not related in any causal way to the architect's intention. The passage concluded, "However much we may wish it, we can hardly follow Professor Asa Gray in his belief."

Science was one thing, but issues of the day were another. Soon afterwards, Darwin nearly argued with Gray over politics. While the Civil War tore America apart, Darwin's feelings ran high--far higher than commonly thought. Gray was a republican, as were most of his relatives. His passions matched Darwin's word for word, and became increasingly strident: “All reason and right and patience appears to be on one side; all madness, audacity, and folly on the other." (Dupree 1988, 307).

From the first talk of Confederate secession until the surrender of the southern states at Appomattox Court House, Darwin was intently engaged: "I never knew the newspapers so profoundly interesting." Every day he would turn first to the reports in The Times by William Howard Russell, the special war correspondent who for Britons was the voice of America in the 
public press. As Adrian Desmond and James Moore have amply demonstrated, Darwin passionately wanted the southern states to abandon slavery (Desmond and Moore 2009). Darwin told Gray that he despaired at President Lincoln's initial sidestepping of the slavery issue in order to defend the union. On the other side of the ocean, Gray ardently supported his president. "The first gun raised my spirits, and they have never flagged since" he declared, showing his Yankee sentiments. For him, the union was the primary issue, not slavery.

All Darwin's abolitionist ardour burst out. "I have not seen or heard of a soul who is not with the North," he wrote emotionally.

Some few, \& I am one, even wish to God, though at the loss of millions of lives, that the North would proclaim a crusade against Slavery. In the long run, a million horrid deaths would be amply repaid in the cause of humanity. . . Great God how I shd like to see that greatest curse on Earth Slavery abolished (Burkhardt and Smith 9, 162-3).

To be sure, Darwin simplified the issues. Although he supported the anti-slavery cause more completely than any other social principle in his life, it was nevertheless relatively easy for him, quietly situated in an English village and buttressed by a private income, to advocate a moral crusade in America. Conveniently, he forgot the colonial and industrial history of British economic wealth, about his own stocks and shares resting on the manual labour of railway navvies, miners, indentured mill-hands, and plantation coolies. Full of humanitarian fervour, he ignored the complex political and personal turmoil through which men like Gray were living. Of course Gray also abhorred the system of slavery. But he found it annoying that his English friend 
took the virtuous high ground without an apparent thought for the terrible, pragmatic realities of maintaining the Union.

On the other hand, the Trent affair of 1861 brought out Darwin's patriotic instincts. Like most Britons, he found it outrageous that a Union ship should intercept and board an English mail boat, even if it carried two Confederate envoys, and said so to Gray. Gray threw Darwin's scientific theories back at him: "We must be strong to be secure and respected--natural selection quickly crushes out weak nations." He accused English politicians of being swayed by the mob. "Hitherto I have been able to write with some sympathy," muttered Darwin to Hooker. "Now I must be silent; for I look at the people as a nation of unmitigated blackguards." The two Englishmen agreed that Gray was "blind to everything \& what is worse brags like the greatest bullies amongst them." For a while they exchanged Gray's letters, "as political and nearly as mad as ever" remarked Darwin as he sent one across to Hooker in November 1862 (Burkhardt and Smith 10, 555-6). Unmoved, Gray lectured them both from across the Atlantic about the North's ability to persevere alone, and issued testy reminders that articles in The Times did not carry as much significance in the United States as Darwin evidently thought. "Homely, honest, ungainly Lincoln is the representative man of the country," Gray insisted. Meanwhile, the textile manufacturing regions of Britain experienced economic distress as supplies of raw cotton from the American South dried up. Despite his dislike of the Confederacy, Darwin fired off a donation of ten guineas to the Lancashire Cotton Spinners' relief fund, far more than he usually gave to charity.

The near-collapse of Union forces defending Washington in the battle of Bull Run stirred him more than expected. 
I have managed to skim the newspaper, but had not heart to read all the bloody details. Good God what will the end be; perhaps we are too despondent here; but I must think you are too hopeful on your side of the water. I never believed the "canard" of the army of the Potomac having capitulated. My good dear wife \& self are come to wish for peace at any price (Burkhardt and Smith10, 330-31).

It was a tense time, although the two never broke off relations. "We must keep to science, I fear, for we both seem to be getting to think each other's country's conduct worse \& worse," Darwin said in April 1863. As The Times switched sides, and Russell was expelled from American soil, Darwin commiserated with Gray, calling the newspaper the "Bloody old Times," like William Cobbett used to do. When the war shuddered to a close Gray exclaimed to him "You see slavery is dead, dead." Darwin reflected sorrowfully on their mutual troubles.

I congratulate you, \& I can do this honestly, as my reason has always urged \& ordered me to be a hearty good wisher for the north, though I could not do so enthusiastically, as I felt we were so hated by you ... I declare I can hardly yet realise the grand, magnificent fact that Slavery is at an end in your country.

Below the surface of this correspondence lay anxious thoughts about Louis Agassiz. Both before and during the Civil War period, Agassiz's definition of species gave scientific credence to the idea of inbuilt human racial differences. On several occasions Agassiz asserted that negroes were a separate species from Caucasians, a point of view that had immediate implications for the anti-slavery movement. For a long time now, Agassiz had been convinced 
that human beings were divided by God into a number of species from the beginning--a logical corollary to his belief in the separate created identity of every living form. Negroes, he proposed, were physiologically and anatomically distinct from whites, created by God to be fixed in their separateness.

So saying, Agassiz joined the controversy over the unity or plurality of the human race, a controversy that had begun decades before Darwin's writings and spread widely across contemporary culture during the 1830s and 1840s, especially in America when given scientific and anthropological significance by Samuel George Morton's study of skulls and Josiah Clark Nott and George Robbins Gliddon's Types of Mankind (Nott and Gliddon 1854) which provided apparent biological justification for a belief in black inferiority. Racial biology, politics, and the origin of species combined in ugly fashion during the war crisis, especially because Agassiz's writings lent scientific authority to those determined to defend the slave system by any means. Agassiz became fixed in his racial, creationist biology. Here was a celebrated man at the head of his adopted nation's intellectual life, a fine naturalist and lover of nature, a staunch supporter of the Union-yet also a staunch believer in separate origins for the races of mankind. Agassiz was altogether a puzzle to his colleagues. His students felt the tension. From 1863 or so, some of them began drifting away from the concepts in the air at Agassiz's museum at Harvard, either attracted by Darwin's alternative universe or developing their own form of non-Darwinian evolution (Winsor 1991).

Opponents like Gray or Lyell were frankly repelled by Agassiz's public pronouncements. Gray-whose dislike for Agassiz was now intense--vented his feelings to Hooker. 
This man, who might have been so useful to science and promised so much here has been for years a delusion, a snare, and a humbug, and is doing us far more harm than he can ever do us good.

These exchanges did much to cement personal relations between Gray, Hooker, and Darwin. In October 1868, during a long scientific tour through Europe, Gray and his wife went to visit Darwin for several days. Magnanimously Gray ignored his differences with Darwin over the Civil War and downplayed Darwin's recent remarks against him in Variation. Together they looked over his experimental work. The visiting botanist—-so active at Harvard in pushing for institutional development, enlarging the herbarium, building offices, expanding the teaching program, working indefatigably to improve the status of botany-- was amused by the simple workbench in Darwin's greenhouse and the turned earth in the kitchen garden ready for next years' scientific peas and beans. To Gray, Darwin seemed to favour working in humble conditions. He went away impressed by his friend's ability to push into unexplored scientific territory armed with only a trowel. Amusingly, however, the most obvious souvenir of Gray's trip was physical. He returned to Boston with a "venerable white beard" just like Darwin's. Reinforced with this badge of allegiance, he promoted Darwinism with the same dedication as before.

Figure 4, figure 5 to go near here

The 1870s were a highpoint in Gray and Darwin's relationship. Insectivorous plants attracted their sustained attention but also many other aspects of plant behaviour and fertilization, all 
considered with a view to evolutionary adaptation. Gray's popular book called How Plants Behave; How they Move, Climb, Employ Insects to work for them (Gray 1874) sold very widely. Darwin's admiration of Gray's knowledge increased through the years, and in 1877 he dedicated The Different Forms of Flowers on Plants of the Same Species to Gray as "a small tribute of respect and affection" (Darwin 1877, preface). His respect for Gray's analytic powers remained high, too. Only a few years before, on publication of the Descent of Man (Darwin 1871) Darwin joked that he would 'probably receive a few stabs from your polished stiletto of a pen.' Gray wrote in return that the final paragraphs of that book were indeed difficult for him to accept. Yet he conceded "Almost thou persuadest me to have been a hairy quadruped, of arboreal habits, furnished with a tail and pointed ears, etc." As it was, Gray continued to believe in the sanctity of mankind until the end.

It seems clear that his and Darwin's religious beliefs by now ran on separate tracks and that towards the end of the century Gray generally found himself at odds with the materialistic tilt of English science (Moore 1979). One small reflection of this was made obvious after Darwin's death when Francis Darwin compiled the Life and Letters of Charles Darwin, published in 1887. Francis Darwin asked Huxley to contribute a chapter on the progress of views about the Origin of Species, an opportunity in which Huxley trenchantly characterised the debate as a conflict between science and religion (F. Darwin 1887, vol. 2, 179-204). As the most prominent advocate in the United States for Darwinism, and the author of widely distributed volume, Darwiniana (Gray 1876), Asa Gray was neither asked to contribute nor would he have framed the postDarwinian controversies in anything like the same light as Huxley. It is curious to reflect on the subsequent hardening of the idea that science and religion must necessarily be opposed. Perhaps 
if Gray's theistic evolution had been given a more obvious place in the construction of the socalled Darwinian revolution, history might have taken a different, more moderate course.

Gray arranged an early retirement from Harvard teaching in 1873 . He found in those later years that he could pinpoint with greater precision his own religious position and its relation with Darwinism. He was still an orthodox member of the Christian church and believed strongly in the reality of a natural theology. With help from the liberal Congregationalist theologian George Frederick Wright, he began to engage more publicly with the theologies of the day, in particular arguing against Charles Hodge's thunderous tract What is Darwinism? (Hodge 1874). Gray, having nearly despaired of convincing scientists that they could also be theists, now tried to convert a theologian into looking kindly on science. This endeavour was the genesis of Gray's admirable little book Darwiniana. Wright persuaded Gray to republish his reviews of Darwin's works in collected form, with one new article written expressly for the volume. In this book, Gray categorically stated that Darwinian evolution did not require either belief or disbelief. Science was neutral, he insisted. Perhaps this was the most valuable aspect of the work. Throughout, and generally running against the tide of events, Gray emphasized the old form of natural theology derived from William Paley: that the existence of adaptations for some specialized function or mode of life indicated that every organ must have a useful purpose. To him this suggested a basic order in the natural world that reflected divine agency.

In the words of Hunter Dupree, Gray's almost unique position as a friend of Darwin's, as a highly esteemed botanical and scientific authority, and now as a reconciler between science and religion, placed new demands on him. One consequence was an interesting extension of his relationship with the Darwin family. In 1880 Gray began a correspondence with Darwin's niece Julia Wedgwood, an independently-minded believer who loosely followed Christian Socialist 
principles. Julia Wedgwood was developing a name as an author in the English literary periodicals. More than most, she recognised that easy accommodation between science and religion was not possible, and she wrote to Gray explaining that his writings were too mild to have an impact in England. In print she defended her uncle's theories while acknowledging that these fought directly with her religious beliefs.

In 1881, Gray made what would be his last visit to England. Once again he went to see Darwin. The two men had long believed that science was, at root, a human enterprise, carried out with courtesy and civility, and that without the communication of results between practitioners science had no obvious way to progress. Their friendship had begun with letters and was reinforced through letters. Over the decades, they exchanged a wealth of experimental information, advice, and publications. Each in their own way had built their scientific lives on the processes of communication. While their books and articles continue to be read for their insights into the biological world, their letters deserve to be better known as a record of the way science used to be done. 
Literature Cited

BARLOW, N. ed. 1958. The autobiography of Charles Darwin 1809-1882. With the original omissions restored. Edited and with appendix and notes by his grand-daughter Nora Barlow. Collins. London.

BROWNE, E. J. 1980. Darwin's botanical arithmetic and the principle of divergence, 1854-1858. J. Hist. Biol. 13(1): 53-89.

BROWNE, E. J. 1995. Charles Darwin: Voyaging. Volume 1. Alfred Knopf Inc., New York. BROWNE, E. J. 2002. Charles Darwin: The Power of Place. Volume 2. Alfred Knopf Inc., New York.

BROWNE, E. J. 2006. Darwin's Origin of Species: A Biography. Atlantic Books, London. BURKHARDT, F.H. and SMITH. S. et al. eds. 1985-. The Correspondence of Charles Darwin. 18 vols. Cambridge University Press, Cambridge.

DARWIN, C.R. 1859. On the origin of species by means of natural selection, or the preservation of favoured races in the struggle for life. John Murray, London.

DARWIN, C. R. 1860. On the origin of species by means of natural selection, or the preservation of favoured races in the struggle for life. New York, D. Appleton.

DARWIN, C.R. 1862. On the various contrivances by which British and foreign orchids are fertilised by insects, and on the good effects of intercrossing. John Murray, London.

DARWIN, C. R. 1868. The Variation of Animals and Plants under Domestication. 2 vols. John Murray, London. 
DARWIN, C. R. 1871. The descent of man, and selection in relation to sex. 2 vols. John Murray, London.

DARWIN, C. R. 1877. The different forms of flowers on plants of the same species. John Murray, London.

DARWIN, C. R. and WALLACE, A. R. 1858. On the Tendency of Species to form Varieties; and on the Perpetuation of Varieties and Species by Natural Means of Selection. Communicated by Sir CHARLES LYELL, F.R.S., F.L.S., and J. D. HOOKER, Esq., M.D., V.P.R.S., F.L.S. [Read 1 July] J. Procs Linn Soc Lond. Zool. 3 (20 August): 46-50.

DARWIN, F. ed. 1887. The life and letters of Charles Darwin, including an autobiographical chapter. 3 vols. John Murray, London.

DESMOND, A.J. and MOORE, J.R. 2009. Darwin's Sacred Cause. Allen Lane, London

DUPREE, A. H. 1988. Asa Gray: American Botanist, Friend of Darwin. Reprint of 1959 ed. The Johns Hopkins University Press, Baltimore.

FREEMAN, R. B. 1977. The works of Charles Darwin: an annotated bibliographical handlist. 2d ed. Dawson, Folkestone, UK.

GAYON, J. and ZALLEN, D. 1998. The role of the Vilmorin Company in the promotion and diffusion of the experimental science of heredity in France, 1840-1920. J. Hist. Biol. 31:241-62.

GRAY, A. 1846. Review of Explanations: A Sequel to vestiges of the Natural History of Creation. Amer.J.Sci. LXII, 465-506.

GRAY, A. 1860a. The Origin of Species by Natural Selection. Amer. J. Sci. March GRAY, A. 1860b. Design versus Necessity.-Discussion between two readers of Darwin's treatise On the Origin of Species, upon its natural Theology. Amer. J. Sci. September 
GRAY, A. 1860c. Natural selection not inconsistent with Natural Theology. Atlantic Monthly July, August, and October, 1860.

GRAY, A. 1874. How plants behave. Ivison, Blakeman, Taylor, and Company, New York.

GRAY, A. 1888. Darwiniana: Essays and Reviews Pertaining to Darwinism. D. Appleton, New York.

HODGE, C. 1874. What is Darwinism? Scribner, Armstrong, New York.

HOME, R. W. and LUCAS, A. M. et al. Eds. 1998-2006. Regardfully Yours: Selected Correspondence of Ferdinand von Mueller. 3 vols. 1840-96. Peter Lang, Bern

MOORE, J. R. 1979. The Post-Darwinian Controversies: A Study of the Protestant struggle to come to terms with Darwin in Great Britain and America, 1870-1900. Cambridge University Press, Cambridge.

NOTT, J. C. and GLIDDON, G. R. 1854. Types of mankind: or, Ethnological researches, based upon the ancient monuments, paintings, sculptures, and crania of races, and upon their natural, geographical, philological and Biblical history; illustrated by selections from the inedited papers of Samuel George Morton ... and by additional contributions from Prof. L. Agassiz. Lippincott, Grambo \& Co., Philadelphia.

SARGENT, C. S. 1889. The Scientific papers of Asa Gray. 2 vols. Houghton Mifflin and Co. Boston.

WINSOR, M. P. 1991. Reading the shape of nature: comparative zoology at the Agassiz Museum. University of Chicago Press, Chicago. 


\section{Captions}

Figure 1. Asa Gray, c.1860. Photograph. Library, Gray Herbarium, Harvard University, 0946.

Figure 2. Charles Darwin, c.1861, photographed by his son William. This photograph was sent by Darwin to Gray as a memento. Library, Gray Herbarium, Harvard University, 0089.

Figure 3. Joseph Dalton Hooker, assistant director of the Royal Botanic Gardens, Kew, c. 1860. Hooker introduced Darwin and Gray in 1839 and again in 1851. He became a close friend to both. Photograph. Library, Gray Herbarium, Harvard University, 0219.

Figure 4. Asa Gray, 1887. Gray grew his beard after a visit to England in 1868, perhaps in imitation of Darwin. Photograph. Library, Gray Herbarium, Harvard University, 1081.

Figure 5. Charles Darwin, c.1870. Steel engraving by C. H. Jeens, published in Nature 9 (4 June 1874): 78, and also issued separately on India paper, from a photograph by O J Rejlander probably taken in 1870 . The portrait has an autograph note from Darwin glued to it, reading "From Charles Darwin Down, Kent Dec $12^{\text {th }}$." Library, Gray Herbarium, Harvard University, 1307.

Figure 6. TBD A page from a letter to Gray from Darwin. Library, Gray Herbarium, Harvard University, $\mathrm{xxxx}$. 